\title{
Productive performance and multivariate interrelations of open-pollinated and hybrid maize in Brazil
}

\author{
C. Troyjack ${ }^{1}$, J.R. Pimentel ${ }^{1}$, I.R. Carvalho ${ }^{2}$, V.J. Szareski ${ }^{1}$, \\ G.T. Junior ${ }^{1}$, I.T.P. Dubal ${ }^{1}$, G.H. Demari ${ }^{1}$, F. Lautenchleger ${ }^{3}$, \\ A.B.N. Martins ${ }^{1}$, F.A. Villela ${ }^{1}$, T.Z. Aumonde ${ }^{1}$ and T. Pedó $^{1}$ \\ ${ }^{1}$ Universidade Federal de Pelotas, Capão do Leão, RS, Brasil \\ ${ }^{2}$ Universidade Regional do Noroeste do Estado do Rio Grande do Sul, Ijuí, \\ RS, Brasil \\ ${ }^{3}$ Universidade Estadual do Centro-Oeste ,Guarapuava, PR, Brasil \\ Corresponding author: I.R. Carvalho \\ E-mail: irc.carvalho@gmail.com \\ Genet. Mol. Res. 18 (3): gmr18180 \\ Received October 08, 2018 \\ Accepted July 01, 2019 \\ Published July 04, 2019 \\ DOI http://dx.doi.org/10.4238/gmr18180
}

\begin{abstract}
Corn is considered one of the most important crops in the world agricultural scenario. In order to improve production, it is crucial to understand and quantify the genetic variation involved in the phenotypic manifestation of this species. We evaluated the agronomic performance of open pollinated genotypes, used by small scale family farmers, compared to commercial hybrid genotypes in various growing environments. The experimental design was a randomized block and the treatments were arranged in four replicates. Eight maize genotypes were used: three open-pollinated varieties and five simple hybrids. The following characters were measured plant height, ear insertion height, stem diameter, ear length, number of seed rows of the ear, number of seeds per row of ear, thousand seed weight and seed yield. The best yields of seeds were obtained in Entre-Ijuís, RS. Seed yield varied according to the genotype and growing environment; in Pelotas, RS the highest yields were obtained with the HC2 and $\mathrm{HC} 1$ genotypes $\left(9090\right.$ and 9002 kg.ha- ${ }^{-1}$, respectively). Genotypes with a narrow genetic base express less variation in their responses to the environments, in contrasting
\end{abstract}


environments. Under limiting conditions the open pollinated varieties responded favorably. The use of biometric approaches allows us to reveal patterns in the grouping of genotypes.

Key words: Zea mays; biometric models; trait associations

\section{INTRODUCTION}

Maize (Zea mays) plays an important agricultural, economic and social role due to the multiplicity of uses, from human and animal feeding, to the production of bioproducts to obtaining biofuels (Ferreira Júnior et al., 2014; Szareski et al., 2018).It is cultivated both as an agricultural commodity in high-level management systems (Argenta et al., 2003; Demari et al., 2018) and in family agriculture, aiming at the subsistence and sustainability of rural properties (Sandri and Tofanelli, 2008).

One of the important components in the definition of maize yield is the genetic base used, distinct technological levels, being a necessary tool for decision making in the management and breeding. The combination of these factors will allow the maximum obtainment of the resources of the environment, seeking to optimize the productivity of the species of agricultural importance in a sustainable way (Argenta et al., 2003; Nardino et al., 2016; Baretta et al., 2017).

In maize crop, genotypes based on open pollinated varieties and simple, modified, double and triple hybrids are commonly used. The choice of genotype is linked to the management practices used, which depend on the farmer's investment capacity. According to Bisognin et al. (1997), the use of open pollinated varieties is economically advantageous for farmers who use low technology investment in their property.

This advantage is due to the lower price of the seeds, the possibility of using the own seeds in subsequent harvests, greater tolerance to biotic and abiotic stresses. According to Tokatlidis and Koutroubas (2004), the superiority of the hybrids can occur in relation to the varieties of open pollination due to the processes of breeding, hybrid vigor and selection.

In spite of the low genetic potential, open-pollinated varieties, under some specific growing conditions, may present superior performance to some maize hybrids (Carvalho et al., 2005; Rosa et al., 2018). The increase in grain yield and the economic return of maize in Brazil depends on the genetic characteristics of the genotype, the management system used by the farmer and the peculiar characteristics of the growing environment. In this way this work had the objective of evaluating the agronomic performance and the positioning of the genotypes of open pollination against normal commercial hybrids in various growing environments.

\section{MATERIAL AND METHODS}

The experiments were conducted in the municipalities of Pelotas $\left(31^{\circ} 52^{\prime} 19^{\prime \prime} \mathrm{S}\right.$ and $\left.52^{\circ} 21^{\prime} 33^{\prime \prime} \mathrm{W}\right)$ and Entre-Ijuís (28 $21^{\prime} 32^{\prime \prime} \mathrm{S}$ and $\left.54^{\circ} 16^{\prime} 04^{\prime \prime} \mathrm{W}\right)$, located at six and $215 \mathrm{~m}$ of altitude, respectively in Rio Grande do Sul state. Seeds from family farmers and from the Research Center of EMBRAPA Temperate Climate - Pelotas were used. 
The experimental design was a randomized block and the treatments were arranged in four replicates. Eight maize genotypes were used: three open-pollinated varieties (PL1, PL2 and PL3) and five simple hybrids (HP1, HP2, HP3, CD1 and CD2). Seeding was done manually, with spacing between rows and plants of 45 and $36 \mathrm{~cm}$, respectively, population density of 55,000 ha $\mathrm{h}^{-1}$ plants (Borghi and Crusciol, 2007). Each experimental unit consisted of six rows $4 \mathrm{~m}$ long, and useful plot area of $5.4 \mathrm{~m}^{2}$.

Seeding of the genotypes was done manually in December 2016, with previously corrected and fertilized experimental area (CQFS RS/SC, 2004). The meteorological attributes based on maximum and minimum air temperature and stratified rainfall for the study environments were recorded (Figure 1). The evaluations were conducted after the physiological maturity of the seeds, based on the following attributes:

- Plant height (PHE): measured by the distance between the soil level to the last fully expanded leaf, results in centimeters.

- Ear insertion height (EHE): distance between ground level and the insertion node of the first viable ear, results in centimeters.

- Stem diameter (SDI): obtained with the aid of a digital caliper where the measurements were standardized, where the equipment was perpendicular to the sowing line, results in millimeters.

- Ear length (ELE): extension between the basal and apical end of the ear, results in centimeters.

- Number of seed rows of the ear (NRE): counting the number of rows with whole seeds in the ear, results in units.

- Number of seeds per row of ear (NSE): of the magnitude of seeds arranged longitudinally in row of ear, results in units.

- Thousand seed weight (TSW): determined according to the Rules of Seed Analysis (Brasil, 2009), results in grams.

- Seed yield (YEI): obtained through the harvest and track of the useful area of each experimental unit, adjusted to $13 \%$ moisture and yield per hectare, results in $\mathrm{kg} \cdot \mathrm{ha}^{-1}$.
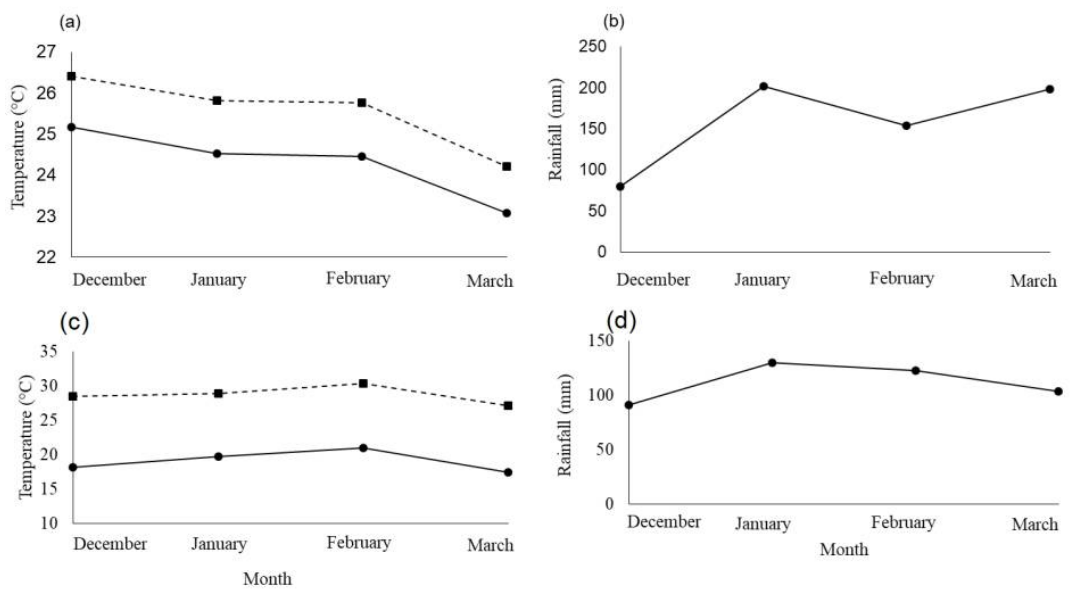

Figure 1. A- monthly averages for the maximum ( - - ) and minimum ( - ) air temperature of Entre-Ijuís. C - monthly averages for the maximum ( - - $)$ ) and minimum ( - ) air temperature of Pelotas. B-Rainfall of Entre-Ijuís. D - Pelotas rainfall during the months of December 2016 to March 2017. Source: São Luiz Gonzaga Meteorological Station and Pelotas Agrometeorology Station. 
In order to identify the multivariate patterns for the selection of the most similar genotypes, an Artificial Neural Networks (ANNs) approach was used, based on estimates through unsupervised computational learning. The topological definition of centroids and associated neurons was obtained by the Kohonen Mapping method. The experimental design was a randomized block in which the treatments were arranged in four replications, being organized in a factorial scheme, being: eight maize genotypes $\mathrm{x}$ two growing environments. The data were submitted to analysis of variance, when the interaction was significant at $5 \%$ probability by the $\mathrm{F}$ test, decomposed into the simple effects; when there was no interaction, the complementary analyses were carried out with a Duncan test at $5 \%$ probability.

\section{RESULTS}

The variance analysis revealed significance for the interaction between maize genotypes $\mathrm{x}$ growing environments at $5 \%$ probability for PHE, ear EHE, SDI, ELE, NRE, NSE, TSW and YEI.

In Pelotas the genotypes HP1, PL1, PL2, HP2 and HC1 had similar performances; the shortest plant heights were found for PL3 and HC2 with magnitudes between 197.5 and $206.4 \mathrm{~cm}$, respectively (Table 1). In Entre-Ijuís the genotypes PL1, HP1, HP3 and HC1 were superior. Among growing environments, Entre-Ijuís, was superior for PHE through the PL1, HP3 and HC1 and HC2 genotypes. According to Gorgulho and Miranda Filho (2001), the height and the insertion of the ear are highly dependent on the characteristics of the genotypes and growing environments. Plant height is determined genetically (Souza et al., 2003; Nardino et al., 2018), influenced by plant population (Brachtvogel et al., 2012) and soil nutrient availability (Paterniani, 1997; Cortez et al., 2009; Repke et al., 2013).

Table 1. Plant height (PHE), stem diameter (SDI), ear insertion height (EHE), number of seed rows per ear (NRE) and number of seeds per row (NSE) measured in different genotypes grown in two environments.

\begin{tabular}{|c|c|c|c|c|c|c|c|c|c|c|}
\hline \multirow[b]{2}{*}{ Genotype } & \multicolumn{2}{|l|}{ PHE (cm) } & \multicolumn{2}{|l|}{ SDI (cm) } & \multicolumn{2}{|l|}{ EHE (cm) } & \multicolumn{2}{|l|}{ NRE } & \multicolumn{2}{|l|}{ NSE } \\
\hline & $\begin{array}{l}\text { Pelotas- } \\
\text { RS }\end{array}$ & $\begin{array}{l}\text { E. Ijuís- } \\
\text { RS }\end{array}$ & $\begin{array}{l}\text { Pelotas- } \\
\text { RS }\end{array}$ & $\begin{array}{l}\text { E. Ijuís- } \\
\text { RS }\end{array}$ & $\begin{array}{l}\text { Pelotas- } \\
\text { RS }\end{array}$ & $\begin{array}{l}\text { E. Ijuís- } \\
\text { RS }\end{array}$ & $\begin{array}{l}\text { Pelotas- } \\
\text { RS }\end{array}$ & $\begin{array}{l}\text { E. Ijuís- } \\
\text { RS }\end{array}$ & $\begin{array}{l}\text { Pelotas- } \\
\text { RS }\end{array}$ & $\begin{array}{l}\text { E. Ijuís- } \\
\text { RS }\end{array}$ \\
\hline PL1 & $226.2 \mathrm{abB} *$ & $248.0 \mathrm{aA}$ & 3.6abc & $3.6 \mathrm{bcd}$ & $120.8 \mathrm{aA}$ & $122.0 \mathrm{aA}$ & $15.0 \mathrm{ab}$ & $16.0 \mathrm{abc}$ & $26.3 b$ & $28.5 \mathrm{a}$ \\
\hline PL2 & 228.8abA & $234.9 \mathrm{bA}$ & $3.2 \mathrm{c}$ & $3.1 \mathrm{de}$ & $122.8 \mathrm{aA}$ & $120.0 \mathrm{abA}$ & $13.5 \mathrm{~b}$ & $14.5 \mathrm{bc}$ & $33.3 \mathrm{a}$ & $34.0 \mathrm{a}$ \\
\hline PL3 & $197.5 \mathrm{cA}$ & $201.5 \mathrm{dA}$ & $3.3 \mathrm{bc}$ & $2.9 \mathrm{e}$ & $96.5 \mathrm{dA}$ & $94.0 \mathrm{dA}$ & $13.5 b$ & $14.0 \mathrm{c}$ & $30.5 \mathrm{ab}$ & $29.2 \mathrm{a}$ \\
\hline HP1 & $234.5 \mathrm{aA}$ & 237.4abA & $4.0 \mathrm{a}$ & $3.7 \mathrm{abc}$ & $121.8 \mathrm{aA}$ & $113.8 \mathrm{bcB}$ & $16.5 \mathrm{a}$ & $17.5 \mathrm{a}$ & $32.5 \mathrm{ab}$ & $33.7 \mathrm{a}$ \\
\hline HP2 & $223.2 \mathrm{abA}$ & $217.6 \mathrm{cA}$ & $3.8 \mathrm{ab}$ & $4.2 \mathrm{a}$ & $118.5 \mathrm{abA}$ & 119.0abA & $16 \mathrm{ab}$ & $17.5 \mathrm{a}$ & $30.8 \mathrm{ab}$ & $29.0 \mathrm{a}$ \\
\hline HP3 & $222.6 \mathrm{bB}$ & 239.7abA & $3.7 \mathrm{abc}$ & $3.4 \mathrm{abc}$ & $120.8 \mathrm{aA}$ & $122.3 \mathrm{aA}$ & $14.5 \mathrm{ab}$ & 15.0abc & 31.0ab & $29.7 \mathrm{a}$ \\
\hline $\mathrm{HC} 1$ & $230.0 \mathrm{abB}$ & $242.3 \mathrm{abA}$ & $3.7 \mathrm{abc}$ & $3.9 \mathrm{ab}$ & $110.0 \mathrm{cA}$ & $110.8 \mathrm{cA}$ & $16.0 \mathrm{ab}$ & $17.0 \mathrm{ab}$ & $28.7 \mathrm{ab}$ & $31.0 \mathrm{a}$ \\
\hline $\mathrm{HC} 2$ & $206.4 \mathrm{cB}$ & $221.2 \mathrm{cA}$ & $3.5 \mathrm{abc}$ & $3.3 \mathrm{cde}$ & $111.5 \mathrm{bcA}$ & $118.5 \mathrm{abA}$ & $15.0 \mathrm{ab}$ & $15.5 \mathrm{abc}$ & $32.7 \mathrm{ab}$ & $34.5 \mathrm{a}$ \\
\hline CV $(\%)$ & 3.2 & & 8.99 & & 4.37 & & 10.69 & & 13.15 & \\
\hline
\end{tabular}

* Averages followed by the same lowercase letter in the column and upper case in the row do not differ statistically by $5 \%$ probability.

The EHE varied according to the genotype and growing environment; for Pelotas there was superiority for the PL1, PL2, HP1, HP2 and HP3 genotypes, in contrast, EntreIjuís showed higher magnitudes for this character through the PL1, HP3, PL2, HP2 and HC2 genotypes. Research by Miranda et al. (2003) define that extremely high plants can increase the probability of lodging. For Cadore (2008), the ear insertion height consists of a characteristic of importance, since smaller distances between the level of the ground and the 
point of ear insertion add the balance of the plant (Santos et al., 2010; Kappes et al., 2013; Rodrigues et al., 2014).

The SDI in Pelotas was higher for the genotypes HP1, HP2, HP3, HC1, HC2 and PL1, however, in Entre-Ijuís larger magnitudes were expressed through genotypes HP1, HP2, HP3 and HC1. The number of seed rows of the ear (NRE) was superior for HP1 genotype in Pelotas. For Entre-Ijuís - RS, this character was superior by genotypes HP1 and HP2.This character is determined by genetic effects (Neto et al., 2003; Valderrama et al., 2011), nutritional levels (Carmo et al., 2012), management (Albuquerque et al., 2013).

Researches define that this attribute is largely influenced by the intrinsic characteristics of the genotype (Fernandes et al., 2005; Valderrama et al., 2011), mineral nutrition (Carmo et al., 2012), ear dimensions (Kappes et al., 2013; Carvalho et al., 2017). The number of seeds per row of the ear did not express great influence of the growing environment, because these environments were in nutritional balance and the magnitude of genotypes studied was not elevated. Research by Freitas et al., (2013), define that this character shows high control of the effects.

The thousand seed weight (TSW) in Pelotas was higher for HC1 and HP3 with 297.86 and $297.45 \mathrm{~g}$, respectively. The smallest magnitudes were obtained through the genotypes PL1, PL2 and PL3. For Entre-Ijuís-RS, it was observed that HC1 was the most productive cultivar (Table 2). Highly agronomic characters based on large numbers of genes and highly influenced by the environment are extremely dependent on the genetic base in the genotype used, the smaller efforts to improve open pollinated varieties result in lower performance of these in relation to high-performance and narrow genetic base hybrids (Sangoi et al., 2006; Cruz et al., 2011; Nardino et al., 2016).

Table 2. Ear length (ELE), thousand seed weight (TSW) and yield (YEI) measured in different genotypes grown in two environments.

\begin{tabular}{|c|c|c|c|c|c|c|}
\hline \multirow{2}{*}{ Genotype } & \multicolumn{2}{|l|}{ ELE (cm) } & \multicolumn{2}{|l|}{ TSW (g) } & \multicolumn{2}{|c|}{ YEI $\left(\mathrm{kg} \mathrm{ha}^{-1}\right)$} \\
\hline & Pelotas-RS & E. Ijuís-RS & Pelotas-RS & E. Ijuís-RS & Pelotas-RS & E. Ijuís-RS \\
\hline PL1 & 16.98 & 17.70 & $234.04 \mathrm{cB}^{*}$ & $270.59 \mathrm{dA}$ & $6277.5 \mathrm{eB}$ & $7391.5 \mathrm{dA}$ \\
\hline PL2 & 16.99 & 17.70 & $252.50 \mathrm{cA}$ & $269.76 \mathrm{dA}$ & $6705.0 \mathrm{dA}$ & $6962.5 \mathrm{eA}$ \\
\hline PL3 & 16.33 & 17.02 & $239.65 \mathrm{cB}$ & $265.37 \mathrm{dA}$ & $6120.0 \mathrm{eA}$ & $6349.0 \mathrm{fA}$ \\
\hline HP1 & 16.41 & 16.12 & 275.17 bA & $280.16 \mathrm{cdA}$ & $8057.5 \mathrm{bcA}$ & $8380.0 \mathrm{bA}$ \\
\hline HP2 & 17.65 & 16.12 & $294.45 \mathrm{abA}$ & $297.37 \mathrm{bcA}$ & $7697.5 \mathrm{cA}$ & $7857.0 \mathrm{cA}$ \\
\hline HP3 & 16.98 & 16.60 & $297.45 \mathrm{aA}$ & $305.70 \mathrm{bA}$ & $8327.5 \mathrm{bB}$ & $9327.0 \mathrm{aA}$ \\
\hline $\mathrm{HC} 1$ & 19.78 & 17.76 & $297.86 \mathrm{aB}$ & $326.45 \mathrm{aA}$ & $9090.0 \mathrm{aA}$ & $9195.0 \mathrm{aA}$ \\
\hline $\mathrm{HC} 2$ & 18.74 & 18.30 & $286.64 \mathrm{abA}$ & $287.36 \mathrm{bcdA}$ & $9001.7 \mathrm{aB}$ & $9533.7 \mathrm{aA}$ \\
\hline $\mathrm{CV}(\%)$ & 12.81 & & 5.12 & & 3.75 & \\
\hline
\end{tabular}

* Averages followed by the same lowercase letter in the column and upper case in the row do not differ statistically by $5 \%$ probability.

In general, the best performances were obtained in Entre-Ijuís - RS, being dependent on the fertility levels (Veloso et al., 2006) and the production system used (Castoldi et al., 2011), climatic conditions in the seed filling stage and temperature (Figure 1) of the air (Floss, 2004). Seed yield (YEI) varied according to the genotype and growing environment, because in Pelotas the highest yields were obtained through the HC2 and HC1

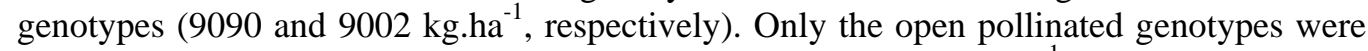
found in Pelotas through the PL2 genotype, yielding $6705 \mathrm{~kg} . \mathrm{ha}^{-1}$.The great variation expressed for this character is due to the phenotypic plasticity that the genotypes present 
due to their broad or narrow genetic base (Emygdeo et al., 2013; Baretta et al., 2017; Carvalho et al., 2017).

The analysis of the linear correlations between the agronomic characteristics measured was established to establish trends among these characters, with significance based on a probability of $5 \%$ by the $t$ test. Eight characters measured in maize genotypes grown under growth environment were used (Figure 2). In this way, the analysis of the linear correlations was carried out in order to establish trends among these characters, with significance based on a $5 \%$ probability by the $t$ test. Eight characters measured in maize genotypes grown in the growing environment were used (Figure 2).

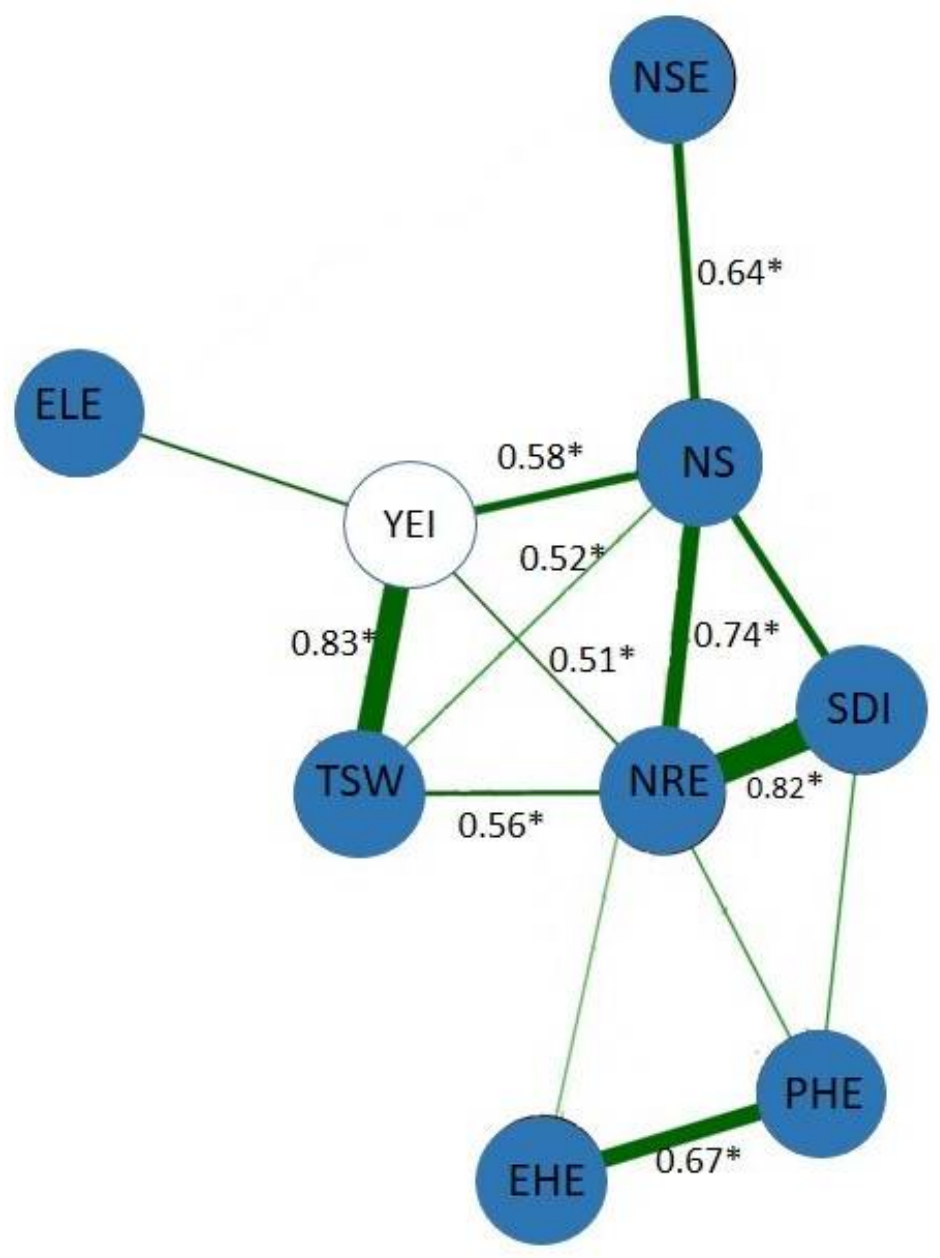

Figure 2. Linear correlation network elaborated for characters plant height (PHE), ear insertion height (EHE), stem diameter (SDI), ear length (ELE), number of seed rows of the ear (NRE), number of seeds per row (NSE), number of seeds per ear (NS), thousand seed weight (TSW) and seed yield (YEI), measured in maize genotypes grown in two environments of Rio Grande do Sul.

The correlation network defined that YEI is strongly associated with TSW, NS and NRE, and the NRE correlates with SDI, NS and TSW. Based on the correlations between 
these attributes, it was defined that the ideal genotype to raise corn seed yields in these growing conditions should be based on the identification of plants that maximize the components of the crop yield.

The use of ANNs is essential to define mathematical patterns through nonlinear stochastic phenomena. In this way, the definition of the network topology is defined by an unsupervised iterative computational process, where the magnitude of network inputs corresponds to the number of neurons associated with the explicability of the model, these neurons when related allow the definition of a centroid that corresponds to the midpoint between the existing associations (Nascimento et al., 2013; Teodoro et al., 2015; Carvalho, 2018). For this study, the use of the Kohonen Mapping method, where the phenotypic matrix was submitted to iterative procedures, defined a neural network with eight centroids that establish associative patterns among the environments and genotypes tested, being necessary 10 synaptic connections to interconnect the centroids (Figure 3).

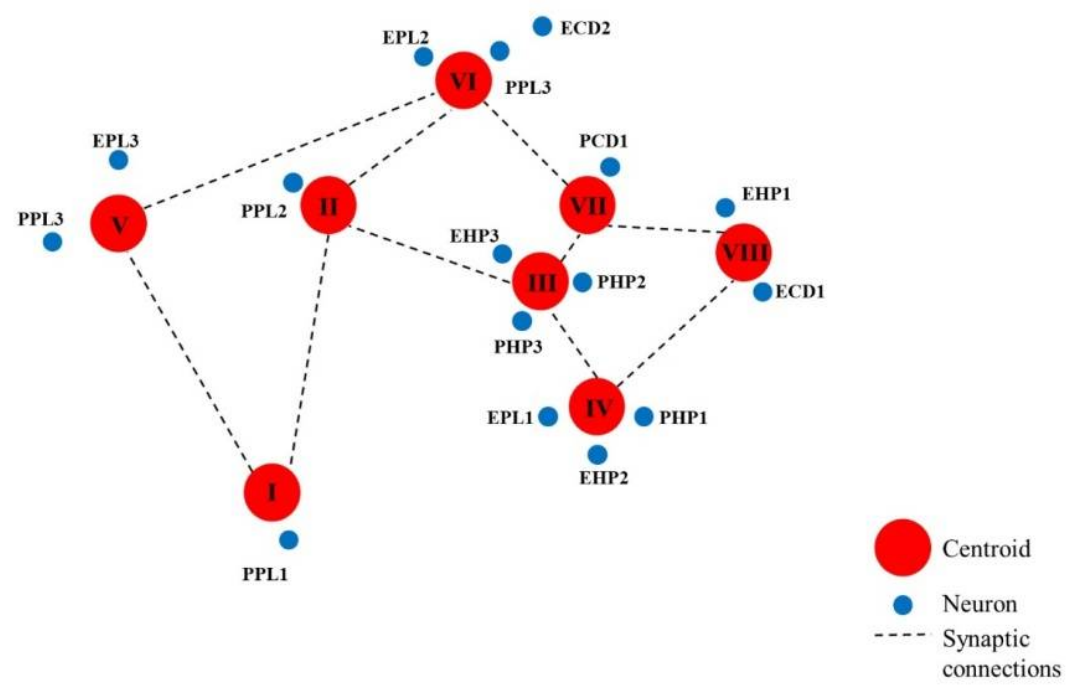

Figure 3. Artificial Neural Networks (ANNs) obtained by the Kohonen Map defining the centroids (red) and the neurons of interest (blue) and the synaptic connections (black dashed lines), these being EPL1, PPL1, EPL2, PPL2, EPL3, PPL3, EHP1, PHP1, EPH2, PHP2, EHP3, PHP3, ECD1, PCD1, ECD2 and PCD2.

The patterns established through the genotypes and their respective growing environment were defined: PPL1 (centroid1); PPL2 (centroid 2); EHP3, PHP2 and PHP3 (centroid 3); PHP1, EPL1 and EHP2 (centroid 4); PPL3 and EPL3 (centroid 5); EPL2, PPL3 and ECD2 (centroid 6); PCD1 (centroid 7); EHP1 and ECD1 (centroid 8). The clusters maintain genotypes grouped in the same centroid due to their similarities of characteristics that establish their proximity, which serves as a tool for the selection of distinct characteristics among genotypes or the choice of genotypes with phenotypic similarity. Based on the computational learning approach, these eight genetic patterns are defined, so the selections can be directed to certain agronomic aspects, with the possibility of identifying the centroid of interest and consequently the group of corresponding genotypes or neurons. 


\section{CONCLUSIONS}

There was variability in the genotypes studied, with higher seed yields in EntreIjuísS. Among the open-pollinated genotypes studied, PL2 showed superiority in the Pelotas environment, with an average yield of $6705 \mathrm{~kg} \cdot \mathrm{ha}^{-1}$, while PL1 genotype was superior in the Entre-Ijuís environment, with a productive average of $7391.5 \mathrm{~kg} \cdot \mathrm{ha}^{-1}$. Among the hybrids, $\mathrm{HC} 1$ and $\mathrm{HC} 2$ presented superiority in the Pelotas culture environment, whereas in the Entre-Ijuís environment the hybrids $\mathrm{HC} 1, \mathrm{HC} 2$ and $\mathrm{HP} 3$ were superior.

Genotypes with a narrow genetic base express less variation in their responses to the environments, in contrasting environments and under limiting conditions the open pollinated varieties respond favorably. The use of biometric approaches allows one to reveal patterns regarding the grouping of genotypes, and the sizes of the groups depend on the intrinsic premises of the genetic variability studied.

\section{REFERENCES}

Albuquerque AW, Santos JR, Filho GM and Reis LS (2013). Plantas de cobertura e adubação nitrogenada na produção de milho em sistema de plantio direto. Rev. Bras. Eng. Agric. Ambient. 17: 721-726.

Argenta G, Sangoi L, Silva PRF Da, Rampazzo C, et al. (2003). Potencial de rendimento de grãos de milho em dois ambientes e cinco sistemas de produção. Scientia Agrária. 4: 27-34.

Baretta D, Nardino M, Carvalho IR, Pelegrin AJ, et al. (2017). Estimates of genetic parameters and genotypic values prediction in maize landrace populations by REML/BLUP procedure. Genet. Mol. Res. 16: 1-14.

Bisognin DA, Ciprandi O, Coimbra JLM and Guidolin AF (1997). Potencial de variedades de polinização aberta de milho em condições adversas de ambiente. Pesq. Agrop. Gaúcha. 3: 29-34.

Borghi E and Crusciol CAC (2007). Produtividade de milho, espaçamento e modalidade de consorciação com Brachiaria brizantha no SPD. Pesq. Agropec. Bras. 42: 163-171.

Brachtvogel ELB, Pereira FRS, Cruz SCS, Abreu MLA, et al. (2012). População, arranjo de plantas uniforme e a competição intraespecífica em milho. Rev. Tropica. 6: 75-83.

BRASIL - Ministério da Agricultura, Pecuária e Abastecimento (2009). Regras para análise de sementes. 1 ed. MAPA/ACS, Brasília.

Cadore T (2008). Potencial de genitores para o melhoramento de milho (Zea mays). Undergraduate thesis. Universidade Comunitária Regional de Chapecó, Chapecó.

Carmo MS Do, Cruz SCS, Souza EJ De, Campos LFC, et al. (2012). Doses e fontes de nitrogênio no desenvolvimento e produtividade da cultura de milho doce (Zea mays convar. saccharata var. rugosa). Biosci. J. 28: 223-231.

Carvalho HWL, Cardoso MJ, Leal MLS, Santos MX, et al. (2005). Adaptabilidade e estabilidade de cultivares de milho no Nordeste brasileiro. Pesq. Agropec. Bras. 40: 471-477.

Carvalho IR, Nardino M, Demari GH, Pelegrin AJ, et al. (2017). Components of variance and inter-relation of important traits for maize (Zea mays) breeding. Aust. J. Crop. Sci. 11: 982-988.

Carvalho IR, Pelegrin AJ, Szareski VJ, Ferrari M, et al. (2017). Diallel and prediction (REML/BLUP) for yield components in intervarietal maize hybrids. Genet. Mol. Res. 16: 1-12.

Carvalho IR, Szareski VJ, Demari GH, Barbosa MH, et al. (2018). Artificial Neural Network and Multivariate Models Applied to Morphological Traits and Seeds of Common Beans Genotypes. J. Agric. Sci. 10: 572-580.

Castoldi G, Costa SSM, Costa LM, Pivetta LA, et al. (2011). Sistemas de cultivo e uso de diferentes adubos na produção de silagem e grãos de milho. Acta. Sci. Agron. 33: 139-146.

Cortez JW, Furlani CEA and Silva RP (2009). Sistemas de adubação e consórcio de culturas intercalares e seus efeitos nas variáveis de colheita da cultura do milho. Eng. Agric. 29: 277-287.

Cruz JC, Viana JHM, Alvarenga RC, Pereira Filho IAP, et al. (2011). Cultivo do milho. Embrapa Milho e Sorgo, Sete Lagoas.

Demari GH, Carvalho IR, Szareski VJ, Follmann DN, et al. (2018). Fontes e parcelamento do nitrogênio em híbridos de milho geneticamente modificados. Rev. Cienc. Agrovet. 17: 325-335.

Emygdio BM, Rosa APSA and Teixeira MCC (2013). Indicações técnicas para o cultivo de milho e de sorgo no Rio Grande do Sul - safras 2013/2014 e 2014/2015. 1 ed. Embrapa Clima Temperado, Pelotas.

Fernandes FCS, Buzetti S, Arf O and Andrade JAC (2005). Doses, eficiência e uso de nitrogênio por seis cultivares de milho. Rev. Bras. Milho Sorgo. 4: 195-204.

Ferreira Júnior RA, Souza JL De, Teodoro I, Lyra GB, et al. (2014). Eficiência do uso da radiação em cultivos de milho em Alagoas. Rev. Bras. Eng. Agric. Ambient. 18: 322-328. 
Floss EM (2004). Fisiologia das plantas cultivadas: o estudo que está por trás do que se vê. 2. ed. Universitária, Passo Fundo.

Freitas RJ, Nascente AS and Santos FLS (2013). População de plantas de milho consorciado com Urochloa ruziziensis. Pesq. Agropec. Trop. 43: 79-87.

Gorgulho EP and Miranda Filho JB De (2001). Estudo da capacidade combinatória de variedades de milho no esquema de cruzamento dialélico parcial. Bragantia. 60: 1-8.

Kappes C, Arf O and Andrade JAC (2013). Produtividade do milho em condições de diferentes manejos do solo e de doses de nitrogênio. Rev. Bras. Cienc. Solo. 37: 1310-1321.

Miranda GV, Coimbra RR, Godoy CL, Souza LV, et al. (2003). Potencial de melhoramento e divergência genética de cultivares de milho-pipoca. Pesq. Agropec. Bras. 38: 681-688.

Nardino M, Baretta D, Carvalho IR, Olivoto T, et al. (2016). REML/BLUP in analysis of pre-commercial simple maize hybrid. Int. J. Curr. Res. 8: 37008-37013.

Nardino M, Baretta D, Carvalho IR, Olivoto T, et al. (2018). Environment Stratification in the Evaluation of Corn Hybrids in Southern Brazil. J. Agric. Sci. 10: 333-342.

Nascimento M, Peternelli LA, Cruz CD, Nascimento ACC, et al. (2013). Artificial neural networks for adaptability and stability evaluation in alfalfa genotypes. Crop Breed. Appl. Biotechnol. 13: 152-156.

Neto DD, Palhares M, Vieira PA, Monfron PA, et al. (2003). Efeito da população de plantas e do espaçamento sobre a produtividade de milho. Rev. Bras. Milho. Sorgo. 2: 63-77.

Paterniani E (1997). Melhoramento do milho. In: Melhoramento de plantas cultivadas (Borém A). UFV, Viçosa.

Repke RA, Cruz SJS, Silva CJ, Figueiredo PG, et al. (2013). Eficiência da Azospirillum brasilense combinada com doses de nitrogênio no desenvolvimento de plantas de milho. Rev. Bras. Milho. Sorgo. 12: 214-226.

Rodrigues MAC, Buzetti S, Filho MCMT, Garcia CMP, et al. (2014). Adubação com KCl revestido na cultura do milho no Cerrado. Rev. Bras. Eng. Agric. Ambient. 18: 127-133.

Rosa TC, Carvalho IR, Szareski VJ, Pelegrin AJ, et al. (2018). Agronomic Performance and Multivariate Analysis Applied to Three-Waycross Maize Hybrids. J. Agric. Sci. 10: 319-328.

Sandri C and Tofanelli MBD (2008). Milho crioulo: uma alternativa para rentabilidade no campo. Pesq. Agropec. Trop. 38: 59-61.

Sangoi L, Ernani PR, Silva PRF Da, Horn D, et al. (2006). Desempenho agronômico de cultivares de milho em quatro sistemas de manejo. Rev. Bras. Milho. Sorgo. 5: 218-231.

Santos PA, Silva AF, Carvalho MAC and Caione G (2010). Adubos verdes e adubação nitrogenada em cobertura no cultivo do milho. Rev. Bras. Milho. Sorgo. 9: 123-134.

Souza AB, Andrade MJB and Muniz JA (2003). Altura de planta e componentes de rendimento do feijoeiro em função da população de plantas, adubação e calagem. Cienc. Agrotec. 27: 1205-1213.

Szareski VJ, Carvalho IR, Kehl K, Pelegrin AJ, et al. (2018). Interrelations of Characters and Multivariate Analysis in Corn. J. Agric. Sci. 10: 187-194.

Teodoro PE, Barroso LMA, Nascimento M, Torres FE, et al. (2015). Redes neurais artificiais para identificar genótipos de feijão-caupi semiprostrado com alta adaptabilidade e estabilidade fenotípicas. Pesq. Agropec. Bras. 50: 10541060 .

Tokatlidis IS and Koutroubas SD (2004). A review of maize hybrids dependence on high plant populations and its implications for crop yield stability. Field Crops Res. 88: 103-114.

Valderrama M, Buzetti S, Benett CGS and Filho MCMT (2011). Fontes e doses de NPK em milho irrigado sob plantio direto. Pesq. Agropec. Trop. 41: 254-263.

Veloso MEC, Duarte SN, Neto DD, Miranda JH, et al. (2006). Doses de nitrogênio na cultura do milho, em solos de várzea, sob sistema de drenagem subterrânea. Rev. Bras. Milho Sorgo. 5: 382-394. 